\title{
Antimalarial Potential of the Leaf Exudate of Aloe macrocarpa Todaro and its Major Constituents against Plasmodium berghei
}

Yitagesu Tewabe ${ }^{1}$ and Solomon Assefa ${ }^{2 *}$

${ }^{1}$ Department of Pharmacognosy and Pharmaceutical Chemistry, School of Pharmacy, Addis Ababa University, Ethiopia

${ }^{2}$ Department of Pharmacology and Clinical Pharmacy, School of Pharmacy, Addis Ababa University, Ethiopia

*Corresponding author: Solomon Assefa, Department of Pharmacology and Clinical Pharmacy, School of Pharmacy, Addis Ababa University, P.O. Box 1176, Addis Ababa, Ethiopia, E-mail: Solomon.assefa@aau.edu.et

Received date: December 20, 2017; Accepted date: January 08, 2018; Published date: January 12, 2018

Copyright: $\odot 2018$ Tewabe $\mathrm{Y}$, et al. This is an open-access article distributed under the terms of the Creative Commons Attribution License, which permits unrestricted use, distribution, and reproduction in any medium, provided the original author and source are credited.

\begin{abstract}
Background:Aloe macrocarpa Todaro is one of the Aloe species in Ethiopia where its leaf exudate is traditionally used for the treatment of various ailments, including malaria.

Methods: Two pure compounds namely aloin and aloinoside were isolated from the leaf exudate. Further oxidative hydrolysis yielded another compound (aloe-emodin). Four-day suppressive test was employed to evaluate the antimalarial potential of the leaf exudates and isolated compounds as well as aloe-emodin against mice infected with Plasmodium berghei.
\end{abstract}

Results: The leaf exudate of $A$. macrocarpa showed significant chemosuppression of $P$. berghei at all dose levels tested compared to the negative control group. At a dose of $400 \mathrm{mg} / \mathrm{kg}$, the leaf exudate of $A$. macrocarpa, the isolated aloin as well as the semi-synthetic derivative (aloe-emodin) suppressed parasite growth by $74.3,64.2$ and $94.7 \%$, respectively, which was statistically significant $(p<0.01)$ compared to the negative control group. Moreover, maximal dose of aloinoside (400 mg) exhibited similar chemosuppression effect $(100 \%)$ and comparable weight loss prevention with chloroquine.

Conclusion: The present study indicated that aloin, aloinoside and aloe-emodin are promising antimalarial principles of $A$. macrocarpa, and further support the traditionally claimed use of the plant against malaria.

Keywords: Antimalarial; Aloe macrocarpa; Plasmodium berghei; Aloin; Aloinside; Aloe-emodin

\section{Background}

Malaria is a protozoal disease caused by Apicomplexan protozoan parasites of the genus Plasmodium [1]. It is one of the most severe public health problems worldwide. It represents the fourth leading cause of death in children under the age of five years in developing countries [2]. Five species of the genus Plasmodium namely: $P$. falciparum, $P$. vivax, $P$. ovale, $P$. malariae and $P$. knowlesi are the causative agents of human malaria [3]. $P$. falciparum causes the most severe form of the disease [4]. It is estimated that half of the world's population (3.3 billion people) live in areas at risk of malaria, mainly in tropical and subtropical regions. With all the efforts made to control malaria, its burden of morbidity and mortality is high in the African region [3]. Some of the main reasons that explain this worsening situation are therapy problems, resistance to the current antimalarial drugs, unavailability and unaffordability of antimalarial drugs and lack of new therapeutic targets [1]. Previous antimalarial drugs discovery taught us how traditional medicines (Artemisia annua L. and bark of Cinchona pubescens Vahl) are valuable in developing new antimalarial drugs [5,6]. Ethiopia is one of the most malaria-epidemic prone countries in Africa in which $P$. falciparum and $P$. vivax are the two dominant malaria species, accounting for $60 \%$ and $40 \%$ of infections, respectively [7,8]. Over $80 \%$ of the Ethiopian population uses traditional medicine due to the cultural acceptability of healers and local pharmacopeias and the relatively lower cost of traditional medicine than modern drugs [9]. Local People in Ethiopia use leaves of Aloe macrocarpa Todaro plant for the treatments of malaria, jaundice and skin diseases. It was reported that $A$. macrocarpa is used to treat many parasitic diseases in Bale Mountains National Park, Southeastern Ethiopia [10,11]. Thus, the present work aimed to test the antimalarial effect of $A$. macrocarpa leaf exudate and its isolated major constituents as well as their derivative.

\section{Methods}

\section{Plant sample collection}

The leaves of A. macrocarpa were collected in March 2017 from Ethiopian Somali region, Jigjiga district. After botanical identification of the plant by an expert taxonomist, a voucher specimen (JJU-YT 001) was deposited at the National Herbarium, of Addis Ababa University, Ethiopia for future reference.

\section{Instruments and apparatus}

Homemade silica gel thin layer chromatography (TLC) plates (Merck, Germany) of $0.25 \mathrm{~mm}$ thickness were used for isolation and analytical chromatographic purposes. Spots were visualized with the aid of UV light. ${ }^{1} \mathrm{H}$ NMR, ${ }^{13} \mathrm{C}$ NMR, and DEPT spectral data were collected using a BrukerAvance DMX400 FT-NMR spectrometer. 
Electron spray ionization mass spectrometry (ESI- MS) was performed by liquid chromatography (LC) coupled with mass spectrometry (MS).

\section{Experimental Animals}

Swiss albino mice of either sex, weighing 25-35 g (age 8-12 weeks), were used in the study. Female mice were used for in vivo acute toxicity test and male mice were used for in vivo antimalarial screening. The mice were obtained from the animal house of Department of Biology, Addis Ababa University, Ethiopia. All animals were acclimatized for a week at room temperature $\left(23-25^{\circ} \mathrm{C}\right)$ with a relative humidity of $60-65 \%$ before starting the study. The animals were maintained on standard pelleted diet and water ad libtum.

\section{Parasite inoculation}

Chloroquine-sensitive strains of Plasmodium berghei (ANKA strain) was obtained from Ethiopian Public Health Institute (EPHI) and maintained by serial passages of blood in mice, weekly. The organism was first inoculated heavily to donor mice which were then subjected to cardiac puncture and blood was collected with an ethylene-diamine-tetraacetic acid (EDTA) coated syringe and immediately diluted with phosphate buffered saline (PBS) so that 0.2 $\mathrm{ml}$ of the blood approximately contained $10^{7}$ of $P$. berghei infected erythrocytes. For the subsequent in vivo test, about $0.2 \mathrm{ml}$ of the blood collected as described by Basir et al. [12] were intraperitoneally inoculated into each non-infected mouse.

\section{Test substances preparation}

Exudate: The leaf exudate of $A$. macrocarpa was collected by cutting the leaves transversally near the base and inclining on a stainless tray. The water was allowed to evaporate upon leaving the latex in open air for two days.

\section{Isolation of Compounds}

The leaf exudate was dissolved in methanol and applied directly to preparative TLC $(20 \times 20 \mathrm{~cm})$ over silica gel of $0.5 \mathrm{~mm}$ thickness. A mixture of chloroform and methanol (4:1) was used for isolation of compounds using preparative TLC. The isolated compounds were further purified by repeated $0.25 \mathrm{~mm}$ thick chromatographic plates. The bands were scraped off, washed with methanol and ethyl acetate (1:1) and filtered.

Aloin: Yellow amorphous solid isolated from the leaf exudates: $\mathrm{R}_{\mathrm{f}}=0.35\left(\mathrm{CHCl}_{3} / \mathrm{MeOH} ; 4: 1\right),(-)$ ESI-MSm/z=417 [M-H]-, $\mathrm{C}_{21} \mathrm{H}_{21} \mathrm{O}_{9}$; ${ }^{1} \mathrm{H}$ NMR (400 MHz, $\mathrm{CDCl}_{3}$ ) $\delta 12.01 / 12.00(1-\mathrm{OH}$, brs), 11.94/11.87(8$\mathrm{OH}$, brs), 7.16/ 7.24(H-2, d), 7.43/7.44 (H-4, d), 7.45/ 7.46 (H-5,d), 7.57/ 7.59(H-6, t), 7.26/ 7.41(H-7, d), 4.45/4.47(H-10, s), 4.82/4.86 (H-15, s), 3.45-4.10 (H-1'-H-6';Glucose). ${ }^{13} \mathrm{C}$ NMR (100MHz, $\mathrm{CDCl}_{3}$ ) $\delta 160.17 / 160.12(\mathrm{C}-1), \quad 113.04 / 112.80 \quad(\mathrm{C}-2), \quad 152.87 / 152.41(\mathrm{C}-3)$, 116.36/116.22 (C-4), 120.48/118.97 (C-5), 136.39/136.15 (C-6), $114.42 / 114.34 \quad$ (C-7), 162.40/162.10 (C-8), 193.36/193.28 (C-9), 62.91/62.83 (C-10), 115.98/115.38 (C-11), 144.81/144.61 (C-12), 115.38/114.42 (C-13), 143.00/142.87 (C-14), 70.19/67.88 (C-15), 61.3783.74 (C-1'-C-6' glucose) determined as aloin [13].

Aloinoside: It was obtained from the exudate of $A$. macrocarpa as a yellow amorphous solid: $\mathrm{R}_{\mathrm{f}}=0.24\left(\mathrm{CHCl}_{3} / \mathrm{MeOH} ; 4: 1\right)(-)$ ESI-MS m/ $\mathrm{z}=563$ [M-H]-, $\mathrm{C}_{27} \mathrm{H}_{32} \mathrm{O}_{13} .{ }^{1} \mathrm{H}$ NMR $\left(400 \mathrm{MHz}, \mathrm{CDCl}_{3}\right) \delta 11.89 / 1185$ (1-OH, brs), 11.80/11.78 (8-OH, brs), 6.88/ 8.85(H-2, d), 7.05/7.02 (H-4, d), 7.01/ 6.89 (H-5,d), 7.54/ 7.51 (H-6, t), 7.08/ 7.06(H-7, d),
4.60/4.58(H-10, s), 4.98/4.97 (H-15, s), 3.40-4.97/3.12-3.37 (H-1'-H-6', $\mathrm{H}-1$ "-H-5"; Glucose \& Rhamnose). ${ }^{13} \mathrm{C}$ NMR $(100 \mathrm{MHz}$, $\left.\mathrm{CDCl}_{3}\right) \delta 161.21 / 159.89 \quad(\mathrm{C}-1), \quad 113.10 / 112.77 \quad(\mathrm{C}-2)$, 145.23/145.08(C-3), $118.26 / 117.97 \quad$ (C-4), $120.71 / 119.36 \quad$ (C-5), $135.69 / 135.41$ (C-6), 116.26/116.20 (C-7), 161.56/161.35 (C-8), 193.93/193.03 (C-9), 44.51/44.36 (C-10), 115.01/114.87 (C-11), 142.47/142.25 (C-12), 117.49/116.87 (C-13), 151.01/146.30 (C-14), 70.56/70.54 (C-15), 61.79-78.5/19.63-99.82 (C-1'-C-6', C-1"C-5"Glucose \& Rhamnose) was identified as aloinoside (Figure 1) [14].

Aloe-emodin: It was obtained as an orange solid through oxidative hydrolysis of aloin and aloinoside: (-) HR-ESIMS $\mathrm{m} / \mathrm{z}=269.0452$ [M$\mathrm{H}]-, \mathrm{C}_{15} \mathrm{H}_{9} \mathrm{O}_{5},{ }^{1} \mathrm{H}$ NMR $\left(400 \mathrm{MHz}, \mathrm{CDCl}_{3}\right) \delta 7.19(1 \mathrm{H}, \mathrm{d}, \mathrm{H}-2), 7.31$ (1H, d, H-7), 7.59 (1H, d, H-4), $7.63(1 \mathrm{H}, \mathrm{d}, \mathrm{H}-5), 7.6(1 \mathrm{H}, \mathrm{dd}, \mathrm{H}-6)$, 4.55 (2H,s, H-11), 11.80 (OH-8 and OH-1, brs). ${ }^{13} \mathrm{C} \mathrm{NMR}(400 \mathrm{MHz}$, $\left.\mathrm{CDCl}_{3}\right) \delta 161.23(\mathrm{C}-1), 120.51(\mathrm{C}-2), 153.62$ (C-3),116.97 (C-4),119.19 (C-5),137.18(C-6),124.22 (C-7),161.54 (C-8), $191.37 \quad$ (C-9), 181.02(C-10), 115.53 (C-11), 133.01 (C-12), 114.08(C-13), 132.77 (C-14), 61.99 (C-15) was confirmed as aloe-emodin (Figure 1) [13].

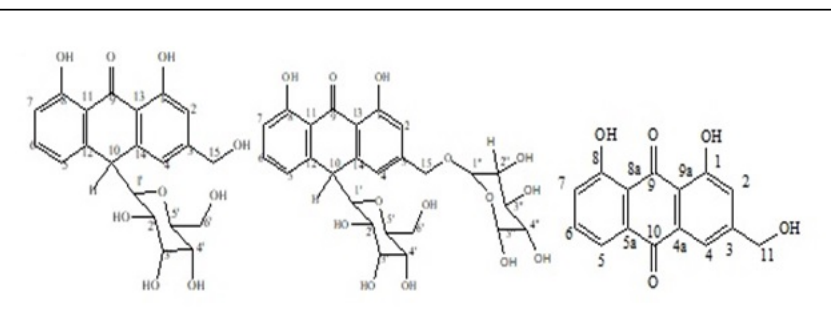

Figure 1: Structure of pure test compounds isolated (aloin and aloinoside) and semi-synthetic (aloe-emodin).

\section{Acute toxicity study}

The acute toxicity study was done according to OECD guideline for testing of chemicals [15]. Six healthy female Swiss albino mice were used for each acute study. Before administration of a single dose of the test substances (leaf exudates and its bioactive compounds), mice have fasted for 2 hours (water allowed) [16]. Each mouse orally received $2000 \mathrm{mg} / \mathrm{kg}$ of the leaf latex of A. macrocarpa and the other test substances. The mice were then observed for toxicity signs such as changes in skin color, blinking eyes, tremors, convulsion, lacrimation, muscle weakness, sedation, urination, salivation, diarrhea, lethargy, sleep, coma and death. Twenty-four hours later, the weight of test mice in each group was recorded [15]. All animals were observed for fourteen days to detect any sign of toxicity and death.

\section{In vivo antimalarial activity test}

In this study, in vivo antiplasmodial activity of the leaf exudates, isolated pure compounds and their semisynthetic derivative against $P$. berghei was evaluated using a 4-day suppressive test described by Peter et al. [17]. Eighty-four male mice were randomly assigned into 14 groups of six mice each (twelve treatment groups and two control groups). Based on the acute toxicity study, treatment groups received three doses $(100,200$ and $400 \mathrm{mg} / \mathrm{kg} /$ day $)$ of the leaf exudate, aloin, aloinoside, and aloe-emodin, for 4 days. The remaining two groups that served as negative and positive controls received $0.5 \mathrm{ml}$ of distilled water and chloroquine $25 \mathrm{mg} / \mathrm{kg}$, respectively. 
Page 3 of 6

All experimental groups were injected intraperitoneally with $0.2 \mathrm{ml}$ of infected blood which was collected from donor mice (parasitemia level 30-37\%) by cardiac puncture [17-19]. Three hours post infection on day $0\left(D^{0}\right)$ treatment groups received 100,200 and $400 \mathrm{mg} / \mathrm{kg}$ of the leaf exudate, aloin, aloinoside and aloe-emodin and then continued daily for four days (from day 0 today 3) [20]. All drug administration was made through the intraperitoneal route. Mice in the negative and positive control group received an intraperitoneal single dose of $0.5 \mathrm{ml}$ of water and $25 \mathrm{mg} / \mathrm{kg}$ of chloroquine. On the $5^{\text {th }}$ day (day 4), thin films were made from the tail blood of each mouse and smeared onto a microscope slide. The blood films were fixed with methanol, stained with $10 \%$ Giemsa at pH 7.2 and parasitemia was examined microscopically to determine parasitemia level and percentage parasite suppression. Six fields were counted for each slide and average percent parasitemia and suppression were calculated using the formula described by Kalra et al. [1].

$$
\% \text { parasitemia }=\frac{\text { Number of } P R B C}{\text { Total number of } R B C} \times 100
$$

Percent parasitemia suppression of the treatment groups was compared with respect to the controls. Percent parasitemia suppression was calculated using the formula [21]:

\section{Average \% of Parasitemia Suppression}

$=\frac{\text { Parasitemia in negative control }- \text { Parasitemia in treatment group }}{\text { Parasitemia in }}$ $\times 100$

Moreover, each mouse was followed for 28 days (Day 0 - Day 27) for determination of their survival time. The mean survival time (MST) for each group was calculated as follows [22]. MST $=\frac{\text { Sum of survival time of all mice in a group (days) }}{\text { Total number of mice in that group }}$

Each mouse in all groups was weighed before infection (day 0 ) and on day 4 using sensitive digital weighing balance (Mettler Toledo, Switzerland).

\section{Determination of packed cell volume (PCV)}

To predict the effectiveness of the leaf exudate and bioactive constituents in preventing hemolysis resulting from increasing parasitemia, packed cell volume (PCV) was monitored before infection and on day 4 after infection. Heparinised capillary tubes were filled up to $3 / 4$ th of their volume with blood obtained by bleeding tail vein of mice and sealed immediately. The tubes were then centrifuged in a microcentrifuge (Centurion Scientific, UK) for $5 \mathrm{~min}$ at $11,000 \mathrm{rpm}$. PCV was calculated using the relation shown below [23].

$$
P C V=\frac{\text { Volume of erythrocytes in a given volume of blood }}{\text { Total blood volume examined }} \times 100
$$

\section{Data analysis}

Results were presented as a mean \pm standard error of the mean (SEM) by using computer software SPSS version 20. The one-way analysis of variance (ANOVA) followed by Tukey's HSD post-hoc test, was used to compare results among and within groups for the difference between initial and final results. Results were deemed statistically significant if $\mathrm{p}<0.05$ at $95 \%$ confidence intervals.

\section{Results}

In acute toxicity studies, the observation of no death or sign of toxicity with an oral dose of $2000 \mathrm{mg} / \mathrm{kg}$ of the tested chemicals showed that exudates and isolated and derived bioactive constituents of the plant are safe for use.

In this study, the leaf exudate of $A$. macrocarpa showed a significant suppression $(\mathrm{p}<0.001)$ of $P$. berghei parasites at all dose levels tested compared to the negative control group (Table 1).

After 4 days of treatment, the mean parasitemia of the test groups ranged from $6.50 \pm 0.55 \%$ to $10.12 \pm 1.33 \%$, while that of the negative control group was $25.30 \pm 1.30 \%$. Aloin isolated from the leaf exudate of $A$. macrocarpa showed significant suppression $(\mathrm{p}<0.05)$ against $P$. berghei at all dose levels compared to the negative control. After 4 days of treatment, aloin displayed the highest suppression of parasitemia $(64.2 \%)$ at a dose of $400 \mathrm{mg} / \mathrm{kg}$ (Table 1).

As it is shown in Table 1, the chemosuppression effect of the isolated compound aloinoside, which showed a dose-dependent chemosuppressive effect $(\mathrm{p}<0.001)$, was $79.1 \%, 90.9 \%$ and $100 \%$ at doses of 100,200 and $400 \mathrm{mg} / \mathrm{kg} / \mathrm{day}$, respectively. The standard drug (chloroquine) at $25 \mathrm{mg} / \mathrm{kg} /$ day and aloinoside $(400 \mathrm{mg} / \mathrm{kg} /$ day) caused $100 \%$ suppression of parasitemia. Compared to negative control, aloeemodin also produced a statistically significant $\quad(\mathrm{p}<0.001)$ chemosuppression.

\begin{tabular}{|l|l|l|l|l|}
\hline Treatment & Dose $(\mathbf{m g} / \mathbf{k g})$ & \% Parasitaemia \pm SEM & \% Suppression & Survival time (days) \pm SEM \\
\hline Exudate & 100 & $10.12 \pm 1.33$ & $60.0 \mathrm{a} 3$ & $8.9 \pm 0.31$ \\
\hline & 200 & $8.13 \pm 0.91$ & $67.8 \mathrm{a} 3$ & $10.5 \pm 0.24 \mathrm{a} 1$ \\
\hline Aloin & 400 & $6.50 \pm 0.55$ & $74.3 \mathrm{a} 3$ & $11.1 \pm 0.52 \mathrm{a} 1$ \\
\hline & 100 & $17.85 \pm 1.02$ & $29.4 \mathrm{a} 2$ & $7.4 \pm 0.21$ \\
\hline Aloinoside & 200 & $13.47 \pm 0.47$ & $46.8 \mathrm{a} 3$ & $8.2 \pm 0.33$ \\
\hline & 400 & $9.05 \pm 0.24$ & $64.2 \mathrm{a} 3 \mathrm{~b} 2$ & $9.4 \pm 0.43 \mathrm{a} 1$ \\
\hline & 100 & $5.29 \pm 0.29$ & $79.1 \mathrm{a} 3$ & $13.0 \pm 0.55 \mathrm{a} 2$ \\
\hline & 200 & $2.31 \pm 0.52$ & $90.9 \mathrm{a} 3$ & $15.2 \pm 0.60 \mathrm{a} 3$ \\
\hline
\end{tabular}


Citation: Tewabe Y, Assefa S (2018) Antimalarial Potential of the Leaf Exudate of Aloe macrocarpa Todaro and its Major Constituents against Plasmodium berghei. Clin Exp Pharmacol 8: 245. doi:10.4172/2161-1459.1000245

Page 4 of 6

\begin{tabular}{|c|c|c|c|c|}
\hline Aloe-emodin & 100 & $8.53 \pm 0.49$ & 66.3a3 & $10.1 \pm 0.32 \mathrm{a} 1$ \\
\hline & 200 & $3.29 \pm 0.30$ & 87a3b1 & $15.8 \pm 0.41 \mathrm{a} 3$ \\
\hline & 400 & $1.33 \pm 0.25$ & $94.7 a 3 b 2$ & $18.2 \pm 0.22 \mathrm{a} 3$ \\
\hline Vehicle & $0.5 \mathrm{ml}$ & $25.30 \pm 1.30$ & - & $6.9 \pm 0.32$ \\
\hline Chloroquine & 25 & 0 & 100 & $26.8 \pm 0.20$ \\
\hline
\end{tabular}

Table 1: Antimalarial activity of the leaf exudate of Aloe macrocarpa, Aloin, Aloinoside and Aloe-emodin in Swiss albino mice infected with Plasmodium berghei. Data are expressed as mean \pm SEM; $\mathrm{n}=6$; $\mathrm{a}=$ compared to distilled water (vehicle); $\mathrm{b}=$ compared to $200 \mathrm{mg} / \mathrm{kg} ; 1=\mathrm{p}<0.05$, $2=\mathrm{p}<0.01,3=\mathrm{p}<0.001$.

Following a 4 day suppressive test, mice in aloinoside and aloeemodin treated group showed a significant $(\mathrm{p}<0.01$ for the lower dose; $\mathrm{p}<0.001$ for middle and higher doses) difference in mean survival time compared to infected mice in negative control group.

Treatment of $P$. berghei infected mice with the exudate of $A$. macrocarpa protected them from weight loss. This improvement was statistically significant $(\mathrm{P}<0.01$ for middle and higher dose, $\mathrm{P}<0.05$ for lower dose), when compared to the negative control.

Aloinoside not only showed antimalarial activity but also significantly protected $(\mathrm{p}<0.001)$ the infected mice from weight loss at $400 \mathrm{mg} / \mathrm{kg} /$ day (Table 2). Mice treated with the higher and middle doses $(200$ and $400 \mathrm{mg} / \mathrm{kg} /$ day) of aloe-emodin showed significant $(p<0.01)$ percent weight increment compared to the negative control group. The highest percent increments $(5.12 \%)$ were recorded in the group treated with $400 \mathrm{mg} / \mathrm{kg} / \mathrm{day}$, while the negative control group showed a decrease in weight $(-5.35 \%)$.

\begin{tabular}{|c|c|c|c|c|}
\hline Treatment & Dose $(\mathrm{mg} / \mathrm{kg})$ & Body weight & & $\%$ Change \\
\hline & & $\mathrm{D}_{0}(\mathrm{~g}) \pm \mathrm{SEM}$ & $\mathrm{D}_{4}(\mathrm{~g}) \pm \mathrm{SEM}$ & \\
\hline \multirow[t]{3}{*}{ Exudate } & 100 & $30.14 \pm 0.72$ & $30.49 \pm 0.59$ & $1.15 a 1$ \\
\hline & 200 & $30.30 \pm 1.27$ & $31.43 \pm 1.30$ & $3.60 a 2$ \\
\hline & 400 & $30.62 \pm 1.98$ & $32.45 \pm 2.24$ & $5.60 \mathrm{a} 2 \mathrm{~b} 1$ \\
\hline \multirow[t]{3}{*}{ Aloin } & 100 & $30.92 \pm 1.58$ & $31.32 \pm 1.32$ & $1.32 \mathrm{a} 1$ \\
\hline & 200 & $30.35 \pm 2.16$ & $30.83 \pm 2.27$ & $1.57 a 1$ \\
\hline & 400 & $29.83 \pm 1.48$ & $30.81 \pm 1.52$ & $3.18 a 2$ \\
\hline \multirow[t]{3}{*}{ Aloinoside } & 100 & $30.19 \pm 1.57$ & $31.18 \pm 1.81$ & $3.18 a 2$ \\
\hline & 200 & $30.18 \pm 1.84$ & $31.78 \pm 1.68$ & $5.03 a 2$ \\
\hline & 400 & $30.57 \pm 1.27$ & $32.55 \pm 1.41$ & $6.08 a 3 b 1$ \\
\hline \multirow[t]{3}{*}{ Aloe-emodin } & 100 & $29.93 \pm 1.70$ & $30.24 \pm 1.65$ & $1.03 a 1$ \\
\hline & 200 & $30.01 \pm 1.22$ & $31.42 \pm 1.07$ & $4.49 a 2$ \\
\hline & 400 & $30.05 \pm 2.66$ & $31.67 \pm 2.66$ & $5.12 \mathrm{a} 2 \mathrm{~b} 1$ \\
\hline vehicle & $0.5 \mathrm{ml}$ & $26.77 \pm 1.82$ & $25.41 \pm 1.19$ & -5.35 \\
\hline Chloroquine & 25 & $28.73 \pm 2.28$ & $31.00 \pm 1.87$ & 7.32 \\
\hline
\end{tabular}

Table 2: Body weight of Plasmodium berghei infected mice after administration of the leaf exudate of Aloe macrocarpa, Aloin, Aloinoside and Aloe-emodin. Data are expressed as mean \pm SEM; $n=6$; $\mathrm{a}=$ compared to distilled water (vehicle); $\mathrm{b}=$ compared to $200 \mathrm{mg} / \mathrm{kg}$; $1=\mathrm{p}<0.05,2=\mathrm{p}<0.01,3=\mathrm{p}<0.001 ; \mathrm{D} 0=$ pre-treatment value on day zero, D4=post-treatment value on day four.

The highest dose $(400 \mathrm{mg} / \mathrm{kg})$ of aloe-emodin, aloinoside and leaf exudates significantly $(\mathrm{p}<0.05)$ prevented PCV reduction compared to the negative control group (Table 3). At day-4, higher dose of aloeemodin almost maintained the PCV in comparison to the preinoculation value (48.60)

\begin{tabular}{|c|c|c|c|c|}
\hline Treatment & $\begin{array}{l}\text { Dose } \\
(\mathrm{mg} / \mathrm{kg})\end{array}$ & $\mathrm{PCV}_{0}$ & $\mathrm{PCV}_{4}$ & $\%$ change \\
\hline \multirow{3}{*}{ Exudate } & 100 & $45.56 \pm 0.55$ & $43.56 \pm 0.45$ & $-3.32 \pm 0.60$ \\
\hline & 200 & $48.43 \pm 0.77$ & $48.31 \pm 1.10$ & $-0.08 \pm 1.11 \mathrm{a} 1$ \\
\hline & 400 & $46.73 \pm 0.94$ & $45.21 \pm 1.12$ & $-1.53 \pm 1.20 \mathrm{a} 1$ \\
\hline \multirow{3}{*}{ Aloin } & 100 & $49.20 \pm 0.25$ & $45.30 \pm 0.30$ & $-7.19 \pm 0.32$ \\
\hline & 200 & $47.31 \pm 1.55$ & $45.25 \pm 1.33$ & $-3.87 \pm 1.27$ \\
\hline & 400 & $48.92 \pm 0.32$ & $47.90 \pm 0.27$ & $-1.38 \pm 0.22 \mathrm{a} 1$ \\
\hline \multirow{3}{*}{ Aloinoside } & 100 & $50.20 \pm 1.03$ & $48.16 \pm 0.66$ & $-3.92 \pm 0.90$ \\
\hline & 200 & $49.41 \pm 0.57$ & $48.54 \pm 0.30$ & $-0.81 \pm 0.40 \mathrm{a} 1$ \\
\hline & 400 & $51.26 \pm 0.35$ & $50.27 \pm 0.20$ & $-0.90 \pm 0.22 \mathrm{a} 1$ \\
\hline \multirow{3}{*}{ Aloe-emodin } & 100 & $48.36 \pm 0.25$ & $46.30 \pm 0.24$ & $-3.56 \pm 0.20$ \\
\hline & 200 & $46.76 \pm 1.30$ & $44.51 \pm 1.55$ & $-2.98 \pm 1.72$ \\
\hline & 400 & $48.60 \pm 1.90$ & $48.25 \pm 1.37$ & $-0.29 \pm 1.50 \mathrm{a} 1$ \\
\hline vehicle & $0.5 \mathrm{ml}$ & $47.20 \pm 1.55$ & $40.89 \pm 1.15$ & $-7.87 \pm 1.19$ \\
\hline Chloroquine & 25 & $48.40 \pm 0.62$ & $49.15 \pm 0.46$ & $1.35 \pm 0.50$ \\
\hline
\end{tabular}

Table 3: Packed cell volume (PCV) of Plasmodium berghei infected mice after administration of the leaf exudate of Aloe macrocarpa, Aloin, Aloinoside and Aloe-emodin. Values are Mean $\pm S E M ; n=6$, $\mathrm{a}=$ compared to distilled water (vehicle); $1=\mathrm{p}<0.05 ; \mathrm{PCV}_{0}=\mathrm{PCV}$ on the day treatment commenced, $\mathrm{PCV}=$ post-treatment value on day four.

\section{Discussion}

In the present study, the latex of $A$. macrocarpa and its bioactive compounds were tested for their acute toxicity using Swiss albino mice according to OECD guideline [15]. None of the mice died or showed signs of acute toxicity within 24 hours of treatment or during the 14 
Page 5 of 6

day observation period. The absence of acute toxicity sign suggested the safety of the test substances and indicated that the $\mathrm{LD}_{50}$ of the test substances is above $2000 \mathrm{mg} / \mathrm{kg}$. In vivo model was also opted for this study because it allows the possible prodrug effect and the likelihood of immune system in eradicating infection as compared to an in vitro study $[24,25]$. Moreover, the 4 -day suppressive test is well known for the development of most antimalarial drugs, including artemisinin derivatives [26].

The leaf exudates of $A$. macrocarpa produced a dose dependent chemo-suppressive effect. The highest suppression of parasitaemia (73.3\%) was observed at a dose of $400 \mathrm{mg} / \mathrm{kg} /$ day which is in agreement with the previous studies on the antimalarial activity of the leaf extracts of Aloe debrana and Aloe sinana [27,28].

Although the exact mechanism of action of the exudate has not been elucidated, some plant extracts exert antiplasmodial activity either by causing erythrocyte oxidation or by inhibiting protein synthesis depending on their phytochemical constituents [29]. Moreover, Bhatia et al. [30] reported that some plant exudates improve immune function of the host that speeds up its recovery from infectious disease. The exudates could have acted through either of the above mentioned mechanisms or by some other mechanism.

A compound is considered to be an active antimalarial agent when it produces a minimum of $30 \%$ parasitemia suppression or when it produces greater percent survival compared to infected non-treated mice [31]. Accordingly, the active constituents of the plant exhibited an active antimalarial effect. The active constituents of the plant may be acting singly or in synergy with one another to exert antiplasmodial activity observed in this study. The higher dose of aloinside prevented body weight loss, which is one feature of rodent malaria infections [32]. The result obtained by aloe-emodin, which exhibited $100 \%$ chemosuppression, was also found to be in line with other in vitro investigation using a chloroquine-sensitive strain of $P$. falciparum [33].

Several classes of natural products including naphthoquinones, anthraquinones, and phenolic glycosides have been reported to possess antimalarial activity, which gives credence to the activity seen by the isolated compounds and their semi-synthetic derivative. The activity possessed by aloin and aloinoside are in a good agreement with other previous investigation [34].

Due to their structural similarity with atovaquone, the mechanism of action for the test compounds may involve inhibition of mitochondrial electron transport in cytochrome bc complex, which is linked to pyrimidine biosynthesis. Moreover, intercalation with parasite DNA due to the cyclic planar structure is another possible mechanism for the antimalarial activity of anthraquinones, which could also be a mechanism for the antimalarial activity of the test compounds [34]. Some phenolic compounds like flavonoids have been shown to inhibit the influx of L-glutamine and myoinositol into infected erythrocytes. Moreover, it is believed that flavonoids act by inhibiting the fatty acid biosynthesis (FAS II) of the parasite. As aloin and aloinoside have phenolic $\mathrm{OH}$ groups, they may exert their action by the same mechanism [35].

Natural products play an important role in the fight against malaria. The final product would be antimalarial chemical entities, potential new drugs or templates for new drugs development, and/or standardized antimalarial extracts which are required for pre-clinical and clinical studies $[36,37]$.

\section{Conclusion}

The present study has demonstrated that the leaf exudates of $A$. macrocarpa and the compounds isolated thereof, aloin, aloinoside, and their semi-synthetic derivative aloe-emodin possess a promising antimalarial activity in a dose-dependent manner, providing the scientific evidence for the folkloric use of the plant. The wider safety margin of the leaf exudates and isolated compounds further makes the plant to be the potential source of leads for possible antimalarial drug development. Therefore, further pharmacological investigations are needed to prove the antiplasmodial mechanism of the compounds.

\section{Competing Interests}

The authors declare that they have no competing interests.

\section{Acknowledgment}

We would like to provide a deepest gratitude and appreciation for Jigjiga University research directorate for the kind support.

\section{References}

1. Kalra BS, Chawla S, Gupta P, Valecha N (2006) Screening of antimalarial drugs. Indian J Pharmacol 38: 5-12.

2. World Health Organization (WHO) (2014) World Malaria Report 2014, Geneva, Switzerland.

3. World Health Organization (WHO) (2016) World malaria report 2016, Geneva, Switzerland.

4. Klotsas E, Lever A (2007) An update on malaria prevention, diagnosis and treatment for the returning traveller. Blood Review 2: 73-87.

5. Adams M, Alther W, Kessler M, Kluge M, Hamburger M (2011) Malaria in the renaissance: Remedies from European herbals from the $16^{\text {th }}$ and $17^{\text {th }}$ century. J Ethnopharmacol 133: 278-288.

6. Liu H, Tian X, Zhang Y, Wang C, Jiang H (2013) The discovery of Artemisia annua L. in the Shengjindian cemetery, Xinjiang, China \& its implications for early uses of traditional Chinese herbal medicine qinghao. J Ethnopharmacol 146: 278-286.

7. Department for International Development (DFID) (2011): Malaria: Country Profiles, version 1.1, pp: 13.

8. Mesfin A, Giday M, Animut A, Teklehaymanot T (2011) Ethnobotanical study of antimalarial plants in Shinile District, Somali Region, Ethiopia, and in vivo evaluation of selected ones against Plasmodium berghei. J Ethnopharmacol 139: 221-227.

9. Kassaye KD, Amberbir A, Getachew B, Mussema Y (2006) A historical overview of traditional medicine practices and policy in Ethiopia. Ethiop J Health Dev 20: 127-134.

10. Demissew S, Nordal I (2003) Flora of Ethiopia and Eritrea. Aloes and Lilies of Ethiopia and Eritrea, pp: 42-43.

11. Yineger H, Kelbessa E, Bekele T, Lulekal E (2008) Plants used in traditional management of human ailments at Bale Mountains National Park, Southeastern Ethiopia. J Med Plants Res 2: 132-153.

12. Basir R, Rahiman SF, Hasballah K, Chong WC, Talib H, et al. (2012) P. berghei ANKA infection in ICR mice as a model of cerebral malaria. Iran J Parasitol 7: 62-74.

13. Dagne E, Bisrat D, Viljoen A, Wyk B (2000) Chemistry of Aloe Species. Curr Org Chem 4: 1055-1078.

14. Tewabe Y, Bisrat D, Terefe G, Asres K (2014) Antitrypanosomal activity of aloin and its derivatives against Trypanosoma congolense field isolate. BMC Vet Res 61: 1-7.

15. OECD guideline for testing of chemicals (2008) Acute Oral Toxicity: Acute Toxic Class Method.

16. Center for Drug Evaluation and Research (CDER) (1996) Guidance for industry single dose acute toxicity testing for chemicals. 
Citation: Tewabe Y, Assefa S (2018) Antimalarial Potential of the Leaf Exudate of Aloe macrocarpa Todaro and its Major Constituents against Plasmodium berghei. Clin Exp Pharmacol 8: 245. doi:10.4172/2161-1459.1000245

Page 6 of 6

17. Peter W, Portus H, Robinson L (1975) The four-day suppressive in vivo antimalarial test. Ann Trop Med Parasitol 69: 155-171.

18. Fidock DA, Rosenthal PJ, Croft SL, Brun R, Nwaka S (2004) Antimalarial Drug Discovery: Efficacy Models for Compound Screening. Nature Rev 3: 509-520.

19. Adumanya O, Uwakwe A, Essien E (2014) Antiplasmodial activity of methanol leaf extract of Salaciasenegalensis Lam (Dc) in Albino Mice infected with chloroquinesensitive Plasmodium berghei (NK65). Int J Ethnopharmacol 1: 2-6.

20. Huang W, Emily P, Charles C (2015) Mouse Models of Uncomplicated and Fatal Malaria. Bio Protoc 5: e1514.

21. Dikasso D, Mekonnen E, Debella A, Abebe D, Urga K et al. (2006) In vivo antimalarial activity of hydroalcoholic extracts from Asparagus africanus Lam. in mice infected with Plasmodium berghe. Ethiop J Health Dev 20: 112-118.

22. Mengiste B, Eyasu M, Kelbessa U (2012) In vivo antimalarial activity of Dodonaea angustifolia seed extracts against $P$. berghei in mice model. MEJS 4(1):47-63.

23. Bantie L, Assefa S, Engidawork E, Teklehaymanot T (2014) In vivo antimalarial activity of the crude leaf extract and solvent fractions of Croton macrostachyus Hocsht. (Euphorbiaceae) against $P$. berghei in mice. BMC Complement Altern Med 14: 79.

24. Waako P, Gumede B, Smith P, Folb PI (2005) The in vitro and in vivo antimalarial activity of Cardiospermum halicacabum and Momordica foetida. J Ethnopharmacol 99: 137-143.

25. Builders M, Wannang N, Aguiyi J (2011) Antiplasmodial activities of Parkia biglobosa: In vivo and in vitro studies. Ann Bio Res 2: 8-20.

26. Peter I, Anatoli V (1998) The current global malaria situation. Malaria parasite biology, pathogenesis, and protection. Washington, DC: ASM Press pp. 11-22.

27. Deressa T, Mekonnen Y, Animut A (2010) In vivo antimalarial activities of Clerodendrum myricoides, Dodonea angustifolia and Aloe debrana against Plasmodium berghei. Ethiop J Health Dev 24: 25-29.
28. Minale G, Bisrat D, Asres K, Mazumder A (2014) In vitro antimicrobial activities of anthrones from the leaf latex of Aloe sinana Reynolds. Int J Green Pharm 8: 7-12.

29. Okokon JE, Ettebong E, Antia BS (2008) In vivo antimalarial activity of ethanolic leaf extract of Stachytarpheta cayennensis. Indian J Pharmacol 40: 111-113.

30. Bhatia RK, Singh L, Garg R, Singh H (2012) Synthesis of novel chromone based thiadiazole derivatives. Int J Nat Prod Sci 1: 122.

31. Krettli A, Adebayo JO, Krettli LG (2009) Testing of natural products and synthetic molecules aiming at new antimalarials. Curr Drug Targets 10: 261-270.

32. Okokon J, Ofodum KC, Ajibesin KK, Danlandi B, Gamaneil KS (2005) Pharmacological screening and evaluation of antiplasmodial activity of Croton zambesicus against $P$. berghei infection in mice. Indian J Pharmacol 37: 243-246.

33. Kumar S, Yadav M, Yadav A, Rohilla P, Yadav PJ (2017) Antiplasmodial potential and quantification of aloin and aloe-emodin in Aloe vera collected from different climatic regions of India. BMC Complement Altern Med 17: 369.

34. Gereziher G, Daniel B, Kaleab A (2014) Isolation, characterization and in vivo antimalarial evaluation of anthrones from the leaf latex of Aloe percrassa Todaro. J Nat Rem 14: 119-126.

35. Perozzo R, Kuo M, Sidhu ABS, Valiyaveettil JT, Bittman R, et al. (2002) Structural elucidation of the specificity of the antibacterial agent triclosan for malarial enoyl acyl carrier protein reductase. J Biol Chem 277: 13106-114.

36. Oliveira AB, Dolabela MF, Braga FC, Jácome RL, Varotti FP, et al. (2009) Plant derived antimalarial agents: new leads and efficient phythomedicines. Part I. Alkaloids. An Acad Bras Cienc 81: 715-740.

37. Alshawsh MA, Mothana RA, Al-Shamahy HA, Alsllami SF, Lindequist U (2009) Assessment of antimalarial activity against Plasmodium falciparum and phytochemical screening of some Yemeni medicinal plants. Evid Based Complement Alternat Med 6: 453-456. 